\title{
The Retrospective Analysis of Abruptio Placenta Cases in a Tertiary Center: Risk Factors and Perinatal Outcomes
}

\author{
Burcu Dinçgez Çakmak ${ }^{1}$, Ülkü Ayşe Türker ${ }^{1}$, (i) Betül Dündar ${ }^{1}$, (1) Ayşe Ender Yumru' \\ ${ }^{1}$ Department of Obstetrics and Gynecology, University of Health Sciences, Bursa Yuksek Ihtisas Research and Training Hospital, Bursa, Turkey \\ ${ }^{2}$ Department of Obstetrics and Gynecology, University of Health Sciences, Sisli Hamidiye Etfal Research and Training Hospital, Istanbul, Turkey
}

\begin{abstract}
Introduction: This study aimed to evaluate risk factors and pregnancy outcomes of abruption cases.

Methods: A total of 91 abruption cases between January 2016 and April 2018 were included in this study. Demographic findings, gestational age, sonographic and clinical findings, predisposing factors, laboratory parameters, birth weight, gender, Apgar scores, neonatal intensive care unit admission, and maternal complications were recorded.

Results: The prevalence was $0.43 \%$; and $65.9 \%$ were multiparous. Preterm birth was present in $70.3 \%$ of cases, hypertension in $40.7 \%$, intrauterine growth restriction in $15.4 \%$, polyhydramnios in $5.5 \%$, cigarette in $17.6 \%$, premature membrane rupture/ preterm delivery in $18.7 \%$, non-vertex presentation in $12.1 \%$, and trauma in $1.1 \%$. The ratio of maternal death was $1.1 \%$, of transfusion $46.2 \%$, of pulmonary edema $1.1 \%$, of acute renal failure $9.9 \%$, of hypovolemic shock $15.4 \%$, and of disseminated intravascular coagulation 13.2\%. The mean gestational week was 33.9 \pm 4.32 , and the mean birth weight was $2337.53 \pm 943.78$ g. Neonates were generally male. The Apgar score was $\leq 7$ in $37.4 \%$ in first and $29.7 \%$ at fifth minutes; and first-minute Apgar score was 0 in $18.7 \%$. The neonatal intensive care unit admission rate was $29.7 \%$.

Discussion and Conclusion: Early diagnosis is crucial for abruption that is related with maternal and fetal mortality. It must be considered when pain and vaginal bleeding is present in third trimester and even sonography is normal. Since at least one risk factor is present in cases, it is important to manage them to prevent complications.

Keywords: Perinatal outcomes; placental abruption; risk factors.
\end{abstract}

B leeding in third trimester complicates $4 \%$ of all pregnancies. Placental abruption is the underlying reason in $80 \%$ of all such bleedings ${ }^{[1,2]}$. Placental abruption is defined as complete or partial detachment of placental tissue from its implantation site because of bleeding occurred in decidua basalis layer before labor initiation [3]. This detachment may be associated with a spectrum of signs and symptoms changing from a clinical presentation with minimal or no effects on perinatal outcomes to one that is together with fetal demise and severe maternal morbidity ${ }^{[4,5]}$. Placental abruption occurs in nearly $0.5 \%-1.8 \%$ of all pregnancies ${ }^{[6,7]}$. Although its etiology is not clearly known, several predisposing factors have been reported ${ }^{[8]}$. The major predisposing factors can be sorted as prior placental abruption history, chronic hypertension/ pre-eclampsia, advanced maternal age, multiparity, polyhydramnios, non-vertex presentation, multiple pregnancy, intrauterine growth restriction, early rupture of mem-

Correspondence (iletişim): Burcu Dinçgez Çakmak, M.D. Saglik Bilimleri Universitesi, Bursa Yuksek Ihtisas Egitim ve Arastirma Hastanesi, Kadin Hastaliklari ve Dogum Bolumu, Bursa, Turkey

Phone (Telefon): +90 5305448828 E-mail (E-posta): burcumavis@gmail.com

Submitted Date (Başvuru Tarihi): 25.08.2018 Accepted Date (Kabul Tarihi): 18.10.2018

Copyright 2019 Haydarpaşa Numune Medical Journal

This is an open access article under the CC BY-NC license (http://creativecommons.org/licenses/by-nc/4.0/). 
branes, smoking, and trauma ${ }^{[8-14]}$. Placental abruption is one of the most important complications of pregnancy. It is associated with increased maternal and fetal mortality and morbidity ${ }^{[6,9]}$. The most common and severe maternal complications, which can be even life-threatening, are requirement of massive transfusion, hemorrhagic shock, requirement of hysterectomy, acute renal failure, and disseminated intravascular coagulation. Prematurity and related complications, fetal hypoxia, and fetal demise are the most commonly encountered perinatal complications ${ }^{[15]}$. Early diagnosis of placental abruption is crucial to prevent its catastrophic clinical consequences ${ }^{[1]}$. Most of the time, placental abruption requires clinical diagnosis. The most common clinical findings are vaginal bleeding, uterine contractions, and pain. Ultrasonographic findings are reported to be present only in $50 \%$ of cases; and normal ultrasonographic findings do not allow ecartation of placental abruption ${ }^{[16]}$.

This study aimed to analyze risk factors, laboratory parameters, and pregnancy outcomes of patients who underwent cesarean section with an initial diagnosis of placental abruption that was confirmed during the operation.

\section{Materials and Methods}

This study was conducted in The University of Health Sciences Bursa Yuksek Ihtisas Research and Training Hospital. We included 91 patients whose initial diagnosis of placental abruption was intraoperatively confirmed during cesarean section between January 2016 and April 2018.

Patient records were obtained from computer system, and patient files were retrospectively analyzed. Age, gravida, parity, gestational age at delivery, the clinical and sonographic findings at first admission, predisposing factors (hypertension, pre-eclampsia, polyhydramnios, non-vertex presentation, early rupture of membranes, preterm labor, intrauterine growth restriction, smoking, trauma), systolicdiastolic blood pressures, hemoglobin level, platelet count, aspartate (AST) and alanine (ALT) aminotransferase levels at first admission, the gender of fetuses, birth weights, first- and fifth-minute Apgar scores, fetal demise rate, neonatal intensive care unit requirement, and maternal complications (disseminated intravascular coagulation, hypovolemic shock, acute renal failure, hysterectomy requirement, pulmonary edema, transfusion requirement, death) were recorded.

Patients who complained of vaginal bleeding, uterine tenderness, and painful uterine contractions together with ultrasonographic findings like subchorionic and retroplacental hematoma, heterogeneity in placental tissue, and increased placental thickness and presence of preplacental and retroplacental collection were initially diagnosed as placental abruption. Definitive diagnosis was made by the macroscopic observation of detached area of placenta, retroplacental bleeding, or coagulum, intraoperatively.

The mean arterial blood pressure was calculated by using the following formula: $[(2 \times$ diastolic blood pressure $)$ + systolic blood pressure]/3. Chronic hypertension was defined as systolic blood pressure $\geq 140 \mathrm{mmHg}$ and diastolic blood pressure $\geq 90 \mathrm{mmHg}$ before 20th gestational week or before pregnancy. Pre-eclampsia was defined as systolic blood pressure $\geq 140 \mathrm{mmHg}$ and diastolic blood pressure $\geq 90 \mathrm{mmHg}$ after 20th gestational week accompanied with proteinuria ( $>300 \mathrm{mg} / 24 \mathrm{~h}$ or +1 by dipstick) or hypertension without proteinuria accompanied with thrombocytopenia, visual symptoms, pulmonary edema, increased serum creatinine levels, and abnormal liver and kidney function tests [17]. The definition of preterm labor was accepted as occurring between 24 and 37 gestational weeks; and that occurring before 34 gestational weeks was accepted as early preterm labor. Rupture of membranes before the onset of labor was classified as early rupture of membranes; and the presence of regular uterine contractions or cervical dilatation before 37 gestational weeks was classified as preterm labor ${ }^{[18]}$. In the neonatal intensive care unit of our hospital, admission criteria are cardiorespiratory monitorization requirement, severe neonatal jaundice, $<32$ weeks preterm births, presence of respiratory distress syndrome, neonatal sepsis, and neonatal blood transfusion requirement.

The SPSS software (IBM Corp. Released 2012. IBM SPSS Statistics for Windows, Version 20. $p=0$. Armonk, NY: IBM Corp.) was used to perform statistical analysis, and a $p$ value of $\leq 0.05$ was considered as statistically significant. The Kolmogorov-Smirnov test was used to assess whether the variables followed normal distribution or not. Normally distributed variables were given as mean \pm standard deviation, and those not normally distributed were given as median. Descriptive statistical analysis was performed. Results were given as numbers and percentages.

In our country, ethical committee approval is not required for retrospective studies; this study was conducted in accordance with the Helsinki Declaration and its later amendments or comparable ethical standards. Moreover, it was approved by the head of the department and the institution. 


\section{Results}

There were 20,964 deliveries in our clinic between January 2016 and April 2018. The frequency of placental abruption was $0.43 \%(91 / 20.964)$. The mean age of patients was $29.19 \pm 6.65$ years, the mean gravidity was 2 (1:11), and the mean parity was $1(0: 10)$. The sociodemographic findings of the study participants are demonstrated in Table 1.

When the patient symptoms at their initial administration to hospital were analyzed, $68.2 \%$ (62/91) were suffering only from vaginal bleeding, $9.9 \%$ (9/91) were suffering only from pain, and $21.9 \%$ (20/91) were suffering from pain accompanied with vaginal bleeding. Ultrasonographic examination confirmed the diagnosis of placental abruption only in 28 (30.8\%) patients.

The maternal risk factors of the patients are displayed in Figure 1. The majority of patients were multiparous (65.9\%). A total of $70.3 \%$ (64/91) patients had preterm labor, and 36 of them were at early preterm period. Hypertensive disorders of pregnancy developed in 37 (40.7\%) patients, and 17

Table 1. Sociodemographic features of study participants

\begin{tabular}{lc}
\hline Age (years) & $29.19 \pm 6.65$ \\
Gravida $(n)$ & $2(1: 11)$ \\
Parity $(n)$ & $1(0: 10)$ \\
Education level & \\
$\quad$ Literate $(n, \%)$ & $14(15.5)$ \\
$\quad$ Primary school $(n, \%)$ & $28(30.8)$ \\
$\quad$ Secondary school $(n, \%)$ & $19(20.9)$ \\
$\quad$ High school $(n, \%)$ & $20(21.9)$ \\
$\quad$ University $(n, \%)$ & $10(10.9)$ \\
Income level & \\
$\quad$ Low $(n, \%)$ & $46(50.4)$ \\
$\quad$ Moderate $(n, \%)$ & $32(35.2)$ \\
High $(n, \%)$ & $13(14.4)$ \\
\hline
\end{tabular}

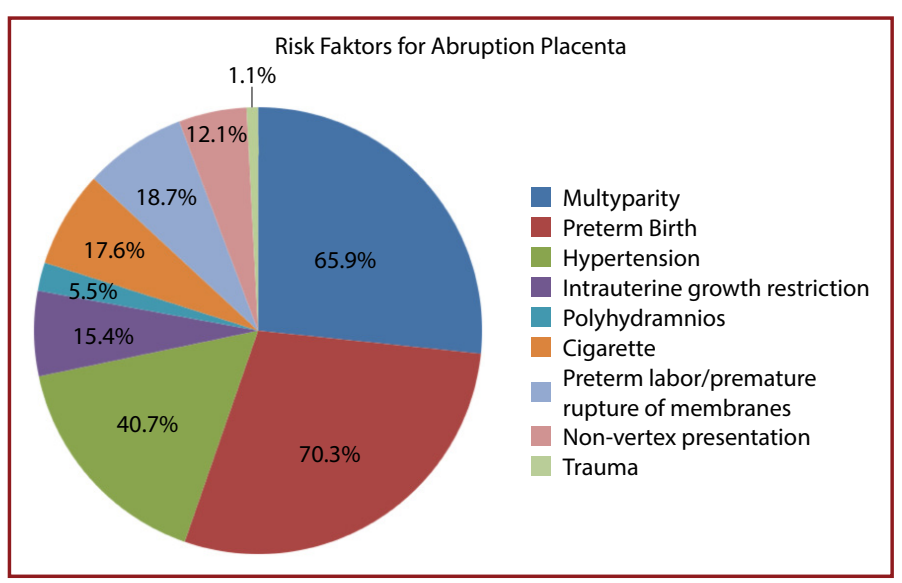

Figure 1. Maternal risk factors for abruptio placenta. of them were diagnosed as with pre-eclampsia.

The mean arterial blood pressure of the patients was $98.4 \pm 18.79 \mathrm{mmHg}$. According to the laboratory findings demonstrated at their initial administration to hospital, the mean hemoglobin level of patients was $9.1 \pm 3.76 \mathrm{~g} / \mathrm{dL}$, platelet count was $183.46 \pm 86.81$ per $\mathrm{mm}^{3}$, serum AST level was $57.81 \pm 19.18 \mathrm{U} / \mathrm{l}$, and serum ALT level was 38.74 \pm 17.21 U/l.

When maternal complications were evaluated, maternal death was determined in $1(1.1 \%)$ patient. A total 42 patients $(46.2 \%)$ had either intraoperative or postoperative transfusion of blood products. Pulmonary edema developed in 1 patient (1.1\%), acute renal failure in 9 patients (9.9\%), hypovolemic shock in 14 patients (15.4\%), and disseminated intravascular coagulation in 12 patients (13.2\%). Hysterectomy was performed in 4 (4.4\%) patients because of postpartum bleeding.

The neonatal outcomes are demonstrated in Table 2. The fetus was male in the most of the placental abruption cases. We analyzed Apgar scores, and we found that the number of cases with an Apgar score $\leq 7$ at first-minute was $34(37.4 \%)$, and the number cases with an Apgar score $\leq 7$ at fifth-minute was 27 (29.7\%). In 17 (18.7\%) of cases, the first-minute Apgar score was reported as "0." The risk factors for perinatal mortality are shown in Table 3.

Table 2. Neonatal outcomes of abruptio placenta

\begin{tabular}{lc}
\hline Gender & \\
$\quad$ Female $(\mathrm{n}, \%)$ & $45(49.5)$ \\
$\quad$ Male $(\mathrm{n}, \%)$ & $46(50.5)$ \\
Gestational age at birth (week) & $33.9 \pm 4.32$ \\
Birth weight (g) & $2337.53 \pm 943.78$ \\
First-minute Apgar score & $5.98 \pm 3.53$ \\
Fifth-minute Apgar score & $6.96 \pm 3.66$ \\
Stillbirth ( $\mathrm{n}, \%)$ & $17(18.7)$ \\
Neonatal intensive care unit admission $(\mathrm{n}, \%)$ & $27(29.7)$
\end{tabular}

Table 3. Risk factors of abruptio placenta for perinatal mortality

\begin{tabular}{lcc}
\hline & Number (n) & Percentage (\%) \\
\hline Multiparity & 6 & 35.3 \\
Preterm birth & 14 & 82.4 \\
Hypertension & 9 & 52.9 \\
Intrauterine growth restriction & 11 & 64.7 \\
Cigarette & 3 & 17.6 \\
Preterm labor/premature & 12 & 70.6 \\
rupture of membranes & & \\
Non-vertex presentation & 1 & 5.9 \\
\hline
\end{tabular}




\section{Discussion}

Placental abruption is defined as abnormal bleeding from small uterine arteries into decidua basalis ${ }^{[19]}$. Although its etiology is not clearly known, the most probable factor is an insufficient trophoblastic invasion [20]. Its prevalence is nearly $0.5 \%-1.8 \%{ }^{[7,21,22]}$. It is reported to be $1 \%$ in the study of Hladky et al. ${ }^{[9]}$ Ulkumen et al. ${ }^{[23]}$ stated the prevalence in Turkey as $0.99 \%$. The prevalence of placental abruption has been reported to be $0.9 \%-1.38 \%$ in several other studies conducted in Turkish population ${ }^{[21,22]}$. In our study, the frequency of placental abruption was found to be lower at $0.43 \%$. The underlying reason may be the close monitorization of patients with risk factors during antenatal surveillance, which could control these modifiable risk factors.

The diagnosis of placental abruption mainly depends on clinical suspicion, but the definitive diagnosis is based on pathologic examination. The most common symptoms are vaginal bleeding and pain that are reported to be observed in $70 \%-80 \%$ of cases ${ }^{[24]}$. Tikkanen et al. ${ }^{[25]}$ reported that $70 \%$ of patients were presented with vaginal bleeding, $51 \%$ with pain, $50 \%$ with bloody amniotic fluid discharge, $69 \%$ with fetal problems, and only in $15 \%$ of patients ultrasonographic findings were in accordance with placental abruptio. In another study, vaginal bleeding was observed in $43.3 \%$ of patients, and vaginal bleeding together with pain was observed in $25 \%$ of patients ${ }^{[16]}$. We found that $68.2 \%$ of patients were admitted to hospital with only vaginal bleeding, $9.9 \%$ with only pain, and $21.9 \%$ with both vaginal bleeding and pain. In our study, the diagnosis of placental abruption was confirmed by ultrasonographic examination only in $30.8 \%$ of patients.

Ultrasonographic findings in patients with placental abruption show variabilities depending on the time of abruption, site of abruption, and the location of placenta ${ }^{[26]}$. Although ultrasonographic findings may not reveal placental abruption, it is important for differential diagnosis of other reasons that may cause vaginal bleeding and/or pain during pregnancy.

In the literature, several risk factors have been defined for placental abruption. Advanced maternal age is one of the risk factors emphasized in the literature. However, it is controversial whether maternal age is an independent risk factor or it increases the risk of placental abruption because of increased ratios of multiparity and adverse pregnancy outcomes among this age group [27]. Matsuda et al. ${ }^{[28]} \mathrm{re}-$ ported being over 35 years of age as an independent risk factor for placental abruption. Moreover, there is another study that reported being over 35 years of age increased 1.5 times the risk of placental abruption ${ }^{[29]}$. The mean age of patients were given as $29.59 \pm 5.68$ years, $30.18 \pm 6.60$ years, and $32.4 \pm 8.9$ years in different studies ${ }^{[7,15,23]}$. In our study, the mean age of patients was found to be $29.19 \pm 6.65$ years. Since the number of patients over 35 years of age was low in our sample, we could not evaluate the accurate effect of age on risk of placental abruption. On the other hand, although the majority of patients included in our study are less than 35 years of age, the majority of patients were multiparous. In the other studies from Turkey, most of the study participants were also reported as multiparous, and the multiparity has been reported as a risk factor for abruption $[7,15]$.

One of the most important risk factors for placental abruption is definitely the hypertensive disorders of pregnancy; and previous studies reported that they increase the risk of placental abruption 2.5 times ${ }^{[30]}$. Anath et al. ${ }^{[31]}$ found that severe and superimposed pre-eclampsia increased placental abruption risk. Moreover, in a study from Pakistan, hypertensive disorders of pregnancy were shown to be associated with placental abruption in $18.7 \%$ of cases ${ }^{[32]}$. This ratio is given as $15.3 \%$ in another study ${ }^{[8]}$. In our country, 2 different studies reported that in $30 \%$ and $53.3 \%$ of cases, placental abruption was accompanied with hypertensive disorders of pregnancy ${ }^{[7,23]}$. In accordance with those, this ratio was found as $40.7 \%$ in our study. The higher ratios reported in our country may be because most of the studies were conducted in tertiary centers.

Smoking increases the risk of placental abruption 2.5 times [33]. Even after the cessation of smoking during pregnancy, the risk of placental abruption remains higher when compared to the normal population ${ }^{[34]}$. The increased levels of homocysteine in smoking women are being accused as the underlying mechanism ${ }^{[35]}$. In our study, the ratio of smoking women was found to be $17.6 \%$ among placental abruption cases. This ratio is lower than the general population; but smoking should be considered as a modifiable risk factor, and developing strategies in this context should be recommended.

The prevalence of placental abruption following a trauma is $2 \%{ }^{[6,15]}$. In our study, history of trauma is reported in one patient (1.1\%). Therefore, in accordance with the recommendations of ACOG, we offer a minimum 4-h followup for pregnant women who had a history of trauma [36].

Preterm labor and early rupture of membranes can be sorted as other risk factors for placental abruption. In the study of Pariente et al., early rupture of membranes was observed in $8.6 \%$ of placental abruption cases ${ }^{[8]}$. In the study 
by Yimaz et al., ${ }^{[15]} 16.3 \%$ of placental abruption cases were observed to be presented together with early rupture of membranes or preterm labor. In accordance with the literature, our ratio was $18.7 \%$.

One of the clinical entities more commonly encountered in placental abruption cases is intrauterine growth restriction. Its frequency among abruption cases was investigated by several investigators, and was reported as $19.6 \%, 14.4 \%$, and $25 \%$ in different studies ${ }^{[2,15,25]}$. We observed intrauterine growth restriction in $15.4 \%$ of placental abruption cases in our study.

In the study of Schiner et al., non-vertex presentation and polyhydramnios were observed in $24.3 \%$ and $6.3 \%$ of placental abruption cases, respectively ${ }^{[37]}$. In the study by Yilmaz et al., ${ }^{[15]}$ these ratios were reported as $20.65 \%$ and $8.69 \%$, respectively. In our study, the frequency of non-vertex presentation was $12.1 \%$ and the polyhydramnios was $5.5 \%$, which were in accordance with the literature.

Placental abruption is known to be associated with increased maternal complications. Development of disseminated intravascular coagulation is nearly $35 \%$, and it is more common among placental abruption cases ${ }^{[27]}$. Also, there is an increase in transfusion requirement due to severe blood loss and consequent development of consumption coagulopathy. Transfusion requirement is reported in nearly $60 \%$ of cases. Moreover, in placental abruption cases, the frequencies of hysterectomy, maternal death, pulmonary edema, and renal failure were reported to be increased because of underlying hypertensive disorders ${ }^{[15]}$. We observed that disseminated intravascular coagulation developed in 12 patients (13.2\%), acute renal failure in 9 patients (9.9\%), pulmonary edema in 1 patient (1.1\%), maternal death in 1 patient (1.1\%), and hypovolemic shock in 14 patients $(15.4 \%)$. The ratio of blood products' transfusion was $46.2 \%$; and hysterectomy was performed in 4 patients (4.4\%) because of postpartum bleeding.

Placental abruption is associated with preterm labor, low birth weight, and fetal demise ${ }^{[2]}$. The perinatal mortality and morbidity of placental abruption depend on the size of placental detachment and the gestational week at which abruption developed. In cases where the area of placental detachment is over $50 \%$, the rate of stillbirth significantly increases ${ }^{[9]}$. In $55 \%$ of abruption cases, perinatal death occurred due to preterm birth. The same study reported that the ratio of low birth weight was $46 \%{ }^{[38]}$. Other studies report the ratio of preterm birth as $36.9 \%$ and $59 \%$ in placental abruption ${ }^{[2,25]}$. Adali et al. ${ }^{[7]}$ reported the mean gestational week as 31.3 and birth weight as $2153 \mathrm{~g}$. Yilmaz et al. found the mean gestational week in abruption cases as 28.25 and mean birth weight as $1988 \mathrm{~g}^{[15]}$. Similarly, we observed that mean gestational week was 33.9 and mean birth weight was $2377 \mathrm{~g}$. In association with all the above risk factors, neonatal asphyxia and death rate increase in case of placental abruption. Furthermore, the neonates generally have lower Apgar scores. In the study of Yilmaz et al. ${ }^{[15]}$, the mean first-minute Apgar score was 4.37. We observed that the first-minute Apgar score was 5.98. In studies conducted on Turkish population, the ratio of fetal death was reported as $22.8 \%-61 \%$ in placental abruption cases, which was $18.7 \%$ in our study ${ }^{[7,15]}$. In addition, Aliyu et al. ${ }^{[39]}$ showed that the risk of placental abruption decreased if the fetus was female. Likewise, we demonstrated that the fetus were male in most of the placental abruption cases.

\section{Conclusion}

To sum up, early diagnosis of placental abruption is very important when its association with maternal-fetal morbidity and mortality is considered. In pregnant women who were admitted to hospital with vaginal bleeding and/ or pain and had normal ultrasonographic examination, placental abruption always should be considered in differential diagnosis. Since in most of the cases at least one risk factor is present, identifying the risk factors and if possible modifying them during antenatal surveillance is crucial to prevent complications.

Peer-review: Externally peer-reviewed.

Conflict of Interest: None declared.

Authorship Contributions: Concept: B.D.Ç., Ü.A.T.; Design: A.E.Y., B.D.; Data Collection or Processing: Ü.A.T., B.D.Ç.; Analysis or Interpretation: B.D., A.E.Y.; Literature Search: Ü.A.T.; Writing: B.D.Ç., B.D., A.E.Y.

Financial Disclosure: The authors declared that this study received no financial support.

\section{References}

1. Keskin N. Preterm Plasenta Previa ve Ablasyo Plasenta Vakalarında Sezaryen Endikasyonlarının Tartışılması. Düzce Tıp Fakültesi Dergisi 2009;11:54-8.

2. Ananth CV, Berkowitz GS, Savitz DA, Lapinski RH. Placental abruption and adverse perinatal outcomes. JAMA 1999;282:1646-51. [CrossRef]

3. Spinillo A, Fazzi E, Stronati M, Ometto A, lasci A, Guaschino S. Severity of abruptio placentae and neurodevelopmental outcome in low birth weight infants. Early Hum Dev 1993;35:4554. [CrossRef]

4. Oyelese Y, Ananth CV. Placental abruption. Obstet Gynecol 
2006;108:1005-16. [CrossRef]

5. Ananth CV, Smulian JC, Srinivas N, Getahun D, Salihu HM. Risk of infant mortality among twins in relation to placental abruption: contributions of preterm birth and restricted fetal growth. Twin Res Hum Genet 2005;8:524-31. [CrossRef]

6. Cunningham FG, Leveno KJ, Bloom SL, Hauth JC, Rouse DJ, Spong CY. Obstetrical Hemorrhage. In: Williams obstetrics. 23nd ed. New York: Mc Graw-Hill; 2010. p. 527-47.

7. Adalı E, Yıldızhan R, Kolusarı A, Kurdoğlu M, Çim N, Özgökçe Ç, et al. Dekolman Plasenta Olgularının Retrospektif Değerlendirilmesi. Van Med J 2009;16: 14-8.

8. Pariente G, Wiznitzer A, Sergienko R, Mazor M, Holcberg G, Sheiner E. Placental abruption: critical analysis of risk factors and perinatal outcomes. J Matern Fetal Neonatal Med 2011;24:698-702. [CrossRef]

9. Hladky K, Yankowitz J, Hansen WF. Placental abruption. Obstet Gynecol Surv 2002;57:299-305. [CrossRef]

10. Rotem R, Pariente G, Golevski M, Baumfeld Y, Yohay D, Weintraub AY. Association between hypertensive disorders of pregnancy and third stage of labor placental complications. Pregnancy Hypertens 2018;13:166-70. [CrossRef]

11. Downes KL, Grantz KL, Shenassa ED. Maternal, Labor, Delivery, and Perinatal Outcomes Associated with Placental Abruption: A Systematic Review. Am J Perinatol 2017;34:935-57. [CrossRef]

12. Jha P, Melendres G, Bijan B, Ormsby E, Chu L, Li CS, et al. Trauma in pregnant women: assessing detection of post-traumatic placentalabruption on contrast-enhanced CT versus ultrasound. Abdom Radiol (NY) 2017;42:1062-67. [CrossRef]

13. Ulander VM, Wartiovaara U, Hiltunen L, Rautanen A, Kaaja R. Thrombophilia: a new potential risk factor for cervical insufficiency. Thromb Res 2006;118:705-8. [CrossRef]

14. Ananth CV, Cnattingius S. Influence of maternal smoking on placental abruption in successive pregnancies: a populationbased prospective cohort study in Sweden. Am J Epidemiol 2007;166:289-95. [CrossRef]

15. Yılmaz M, İsaoğlu Ü, Delibaş İB, Uluğ P, İngeç M, AI RA. Dekolman Plasenta: Epidemiyoloji, Risk Faktörlerinin Analizi, Fetal ve Maternal Sonuçlar. Sakaryamj 2013;3:126-130.

16. Bostancı E, Arısoy R, Polat M, Erdoğdu E, Karakuş R, Boza A, et al. Dekolman plasenta ve risk faktörleri. Perinatoloji Dergisi 2013;21:60-5.

17. American College of Obstetricians and Gynecologists; Task Force on Hypertension in Pregnancy. Hypertension in pregnancy. Report of the American College of Obstetricians and Gynecologists' Task Force on Hypertension in Pregnancy. Obstet Gynecol 2013;122:1122-31.

18. Menon R, Fortunato SJ. Infection and the role of inflammation in preterm premature rupture of the membranes. Best Pract Res Clin Obstet Gynaecol 2007;21:467-78. [CrossRef]

19. Eskes TK. Abruptio placentae. A "classic" dedicated to Elizabeth Ramsey. Eur J Obstet Gynecol Reprod Biol 1997;75:6370. [CrossRef]

20. Dommisse J, Tiltman AJ. Placental bed biopsies in placental abruption. Br J Obstet Gynaecol 1992;99:651-4. [CrossRef]

21. Kale A, Ecer S. Dekolman Plasenta Olgularının Retrospektif Analizi ve Normal Gebeliklerle Karşılaştırılması. Dicle Tıp Dergisi 2005;32:161-64.

22. Çetin İ, Küçükbaş M, Dayıcıoğlu V, Vatansever D. Plasenta dekolmanı; risk faktörleri, takip-tedavi protokollerimiz ve sonuçları. Zeynep Kamil Tıp Bülteni 2009;40:159-65.

23. Ülkümen BA, Pala HG, Çalık E, Koyuncu FM. Ablasyo Plasenta Olgularının Retrospektif Olarak Değerlendirilmesi. DEÜ Tıp Fakültesi Dergisi 2014;28:15-9. [CrossRef]

24. Tikkanen M. Etiology, clinical manifestations, and prediction of placental abruption. Acta Obstet Gynecol Scand 2010;89:73240. [CrossRef]

25. Tikkanen M, Nuutila M, Hiilesmaa V, Paavonen J, Ylikorkala O. Clinical presentation and risk factors of placental abruption. Acta Obstet Gynecol Scand 2006;85:700-5. [CrossRef]

26. Shinde GR, Vaswani BP, Patange RP, Laddad MM, Bhosale RB. Diagnostic Performance of Ultrasonography for Detection of Abruption and Its Clinical Correlation and Maternal and Foetal Outcome. J Clin Diagn Res 2016;10:QC04-7. [CrossRef]

27. Konje JC, Taylor DJ. Bleeding in late pregnancy. In: James DK, Steer PJ, Weiner CP, Gonik B (eds). High risk pregnancy, 3rd edn. Edinburgh, UK: WB Saunders: 2006.

28. Matsuda Y, Hayashi K, Shiozaki A, Kawamichi Y, Satoh S, Saito S. Comparison of risk factors for placental abruption and placenta previa: case-cohort study. J Obstet Gynaecol Res 2011;37:538-46. [CrossRef]

29. Hung TH, Hsieh CC, Hsu JJ, Lo LM, Chiu TH, Hsieh TT. Risk factors for placental abruption in an Asian population. Reprod Sci 2007;14:59-65. [CrossRef]

30. Abdella TN, Sibai BM, Hays JM Jr, Anderson GD. Relationship of hypertensive disease to abruptio placentae. Obstet Gynecol 1984;63:365-70.

31. Ananth CV, Savitz DA, Bowes WA Jr, Luther ER. Influence of hypertensive disorders and cigarette smoking on placental abruption and uterine bleeding during pregnancy. Br J Obstet Gynaecol 1997;104:572-8. [CrossRef]

32. Abbasi RM, Rizwan N, Mumtaz F, Farooq S. Feto Maternal Outcome Among Abruptio Placentae Cases at a University Hospital of Sindh. JLUMHS 2008;7:106-9. [CrossRef]

33. Kaminsky LM, Ananth CV, Prasad V, Nath C, Vintzileos AM, New Jersey Placental Abruption Study Investigators. The influence of maternal cigarette smoking on placental pathology in pregnancies complicated by abruption. Am J Obstet Gynecol 2007;197:275.e1-5. [CrossRef]

34. Castles A, Adams EK, Melvin CL, Kelsch C, Boulton ML. Effects of smoking during pregnancy. Five meta-analyses. Am J Prev Med 1999;16:208-15. [CrossRef]

35. Eskes TK. Clotting disorders and placental abruption: homocysteine--a new risk factor. Eur J Obstet Gynecol Reprod Biol 2001;95:206-12. [CrossRef]

36. ACOG educational bulletin. Obstetric aspects of trauma management. Number 251, September 1998 (replaces Number 
151, January 1991, and Number 161, November 1991). American College of Obstetricians and Gynecologists. Int J Gynaecol Obstet 1999;64:87-94.

37. Sheiner E, Shoham-Vardi I, Hadar A, Hallak M, Hackmon R, Mazor M. Incidence, obstetric risk factors and pregnancy outcome of preterm placental abruption: a retrospective analysis.
J Matern Fetal Neonatal Med 2002 Jan;11:34-9. [CrossRef]

38. Ananth CV, Wilcox AJ. Placental abruption and perinatal mortality in the United States. Am J Epidemiol 2001;153:332-7.

39. Aliyu MH, Salihu HM, Lynch O, Alio AP, Marty PJ. Placental abruption, offspring sex, and birth outcomes in a large cohort of mothers. J Matern Fetal Neonatal Med 2012;25:248-52. 